\title{
CORRECTION
}

\section{Correction to: Review of oil palm-derived activated carbon for $\mathrm{CO}_{2}$ capture}

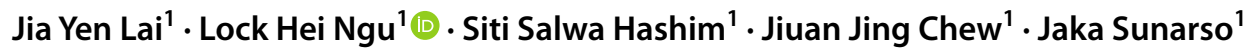

Published online: 15 February 2021

(c) Korean Carbon Society 2021

\section{Correction to: Carbon Letters}

https://doi.org/10.1007/s42823-020-00206-1

Due to an unfortunate oversight during the article preparation the temperature for oxy-combustion $\mathrm{CO}_{2}$ capture technology in Table 1 is $-55^{\circ} \mathrm{C}$ but not $<50-55^{\circ} \mathrm{C}$.

Table 1 Typical process conditions for CCS technology [8, 12-17, 270-272]

\begin{tabular}{llll}
\hline CCS technology & $\begin{array}{l}\text { Typical pres- } \\
\text { sure (bar) }\end{array}$ & Temperature $\left({ }^{\circ} \mathrm{C}\right)$ & $\begin{array}{l}\mathrm{CO}_{2} \text { con- } \\
\text { centration } \\
(\%)\end{array}$ \\
\hline Pre-combustion & $14-70$ & $200-450$ & $15-60$ \\
Oxy-combustion & 1 & -55 & $17-70$ \\
Post-combustion & 1 & $40-60$ & $3-20$ \\
Direct air capture & 1 & 25 & $\sim 0.04$ \\
\hline
\end{tabular}

Publisher's Note Springer Nature remains neutral with regard to jurisdictional claims in published maps and institutional affiliations.

The original article can be found online at https://doi.org/10.1007/ s42823-020-00206-1.

\footnotetext{
Lock Hei Ngu

lngu@swinburne.edu.my

1 Research Centre for Sustainable Technologies, Faculty of Engineering, Computing and Science, Swinburne University of Technology, Jalan Simpang Tiga, 93350 Kuching, Sarawak, Malaysia
} 